\title{
STRAIGHT FROM THE ARCHIVES \\ Reflections about Professional Engagement with LGBTQ+ Lives
}

SQS

$1-2 / 2020$

56

Tom Furber

\section{ABSTRACT}

As records of LGBTQ+ experiences become more integrated into the wider historical record, many of us who work with archives are finding that our first exposure to LGBTQ+ records is professional rather than personal. Here I will share some of my practice and reflections on working with archives of LGBTQ+ experiences from the perspective of someone who does not identify as LGBTQ+. I discuss, proactively collecting oral histories, revisiting catalogue descriptions and adding new sets of search terms, working respectfully with personal collections and using LGBTQ+ collections in general and dedicated events, education and community programmes.

\section{ABSTRAKTI}

LGBTQ+ kokemuksia käsittelevien aineistojen yhtyessä enenevässä määrin yleisempään historialliseen aineistoon monet arkistojen parissa työskentelevistä tunnistavat, kuinka ensikosketuksemme LGBTQ+ arkistoihin on pikemminkin ammatillinen kuin henkilökohtainen. Tekstissäni pyrin valaisemaan ammatillisia työtapoja ja välittämään kokemuksia arkistotallennustyöstä sellaisen henkilön näkökulmasta, joka ei identifioidu LGBTQ+ henkilöksi. Käsittelen muistitietoaineistojen aktiivista keräämistä, uusien sisältöluokittelujen ja hakutermien käyttöönottoa sekä LGBTQ+ kokoelmien kunnioittavaa käsittelyä ja käyttöä niin yleisille kuin spesifeille kohderyhmillekin suunnatuissa koulutuksissa ja yhteisöllisissä tapahtumissa.

\section{Introduction}

As records of LGBTQ+ experiences become more integrated into the wider historical record, many of us who work with archives are finding that our first exposure to LGBTQ+ records is professional rather than personal. Here I will share some of my practice and reflections on working with archives of LGBTQ+ experiences from the perspective of someone who does not identify as LGBTQ+ but works extensively with these archives as part of a wider portfolio of work.

I am not strictly speaking an archivist, which in a UK context is a specific professional title. Rather, I am an Engagement and Learning Officer with a remit of informal adult education and community projects. I have worked at London Metropolitan Archives (LMA) for the past 5 years and it will be this experience I draw on here.

By way of background, LMA is a large local authority archive covering all of London with around $100 \mathrm{~km}$ of records dating back to 1067 . These holdings include records of local

\section{LGBTQ+}

LONDON METROPOLITAN ARCHIVES
Tom Furber 
government, churches, hospitals, prisons, businesses as well as records of individuals and communities. The collections are in a variety of formats including documents, books, maps, sound recordings, films and photographs.

LMA is an established presence in the field of LGBTQ+ history with wellregarded collections, events and community engagement programmes. As part of this wider scheme of work, I administer several programmes that cultivate and share LGBTQ+ perspectives on archives and history.

In this piece I will discuss issues that help to inform and guide this work, some of the policies and programmes that stem from them and some reflections and examples of my personal practice. In turn we will look at: proactively collecting oral histories, revisiting catalogue descriptions working respectfully with personal collections, and education programs.

\section{Evidencing other sides of the past}

For me, the simultaneous rewards and frustrations of working with archives are aptly captured by a couple of lines from Arthur Marwick. "Primary sources are full of prejudices and errors. They were not written to serve the interests of historians coming along later: they were written to serve the interests of those who created them, going about their own business." (Marwick 2001). To many a contemporary reader working with archives of LGBTQ+ lives these prejudices and errors are particularly stark. LMA's collections date back to 1067 and for most of this period LGBTQ+ people and their experiences have been marginalised.LGBTQ+ people have been variously depicted as criminal, ill or immoral with prosecution, medical intervention and moral judgement the results.
Our records relating to LGBTQ+ lives, like those in many other repositories, are often not a record of the lives themselves but other people's judgements on those lives. Thankfully, this isn't always the case, especially when dealing with more recent history. At LMA deposits by Peter Tatchell, Kenric, Ruckus!, ${ }^{1}$ and others offer an alternative view on LGBTQ+ history that evidence LGBTQ+ lives from a community perspective. The clear value and richness of this perspective is a challenge to further evidence LGBTQ+ people through their own experiences and in their own voice.

LMA responses to this challenge include:

- Proactively collecting oral histories

- Revisiting catalogue descriptions and adding new sets of search terms

- Working Respectfully with Personal Collections

- Using LGBTQ+ collections in general and dedicated events, education and community programmes

\section{Proactively collecting oral histories}

The different approach offered by oral histories is valuable in a range of contexts but is especially so for LGBTQ+ histories. This is because for much of history the activities of LGBTQ+ people were taboo and in some cases illegal. As a consequence, central aspects of sexual, romantic and social relationships often do not exist on paper as to record them was to risk persecution and prosecution. Gathering oral histories allows people to speak about those very experiences that are otherwise likely to go undocumented.

As part of a project called Speak Out London Diversity City supported by the then Heritage Lottery Fund (now National Lottery Heritage Fund)

1 Peter Tatchell ia British gay activist; Kenric a lesbian network of social clubs; Ruckus! a Black LGBT archive.

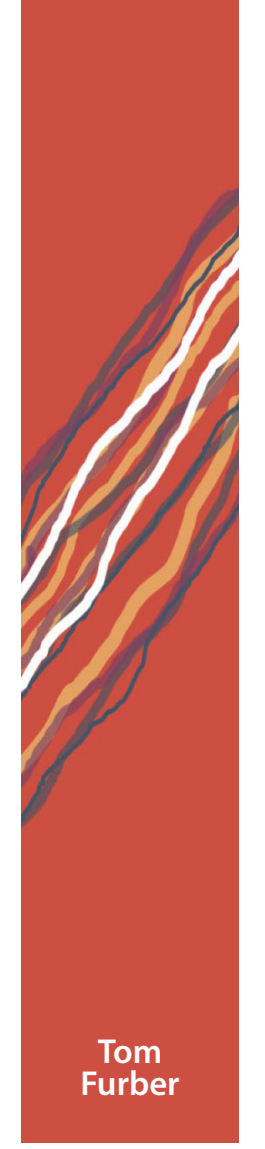


over 50 oral histories were conducted by combination of an experienced oral historian and by a cohort of volunteers that she trained. As part of this training the trainer asserted that it is better if both the interviewer and participant are LGBTQ + . Her reasoning being that trust and rapport are more easily established and that some experiences that might produce shock or judgement in a non-LGBTQ+ person can be understood in context. This gave me some pause for thought at the time and I continue to reflect on the fundamental, complex and contentious issues of epistemology raised by her assertion. In my practice, I moved from an initial reaction of "that could be true but ultimately I don't think that it is, on a philosophical level" to a more settled and pragmatic position of "it is more true than it isn't and it is a reminder of the need for professional and personal humility". This is an important lesson learned early on that I have carried with me working with all types of archives.

\section{Revisiting catalogue descriptions and adding new sets of search terms}

Recognising the limits of an individual's experience and knowledge is important in dealing with language that is archaic and potentially offensive. Records and their catalogue descriptions frequently use terms which reflect the marginalisation of LGBTQ+ people. For example, to locate LGBTQ+ archives you may need to use search terms such as "buggery"," sodomy", "gross immorality" and "gross indecency". The terms noted above are often legal or otherwise technical. It therefore requires a degree of specialist knowledge to know which terms are likely to generate which kind of results. This creates a purely practical problem in that it makes records harder to find. Furthermore, as the terms change over time one must run multiple searches to bring up records from different time periods. For the veteran and dedicated researcher these are problems that can be overcome but they are a barrier to entry for the more casual researcher.
On a deeper level it is inhospitable, and to my mind frankly unjust to require people to research their history in terms that are the product of systems of persecution and marginalisation. Forced repetition of these terms not only perpetuates the norms behind them but in some cases can invoke past traumas.

However, as such archaic terms are themselves part of the historical record to remove them would be a different kind of distortion. At LMA we therefore decided to add a new level of description with more familiar tags whilst still preserving the older descriptions. The selection of tags was a collaborative process with a group of over a hundred volunteers who defined themselves as LGBTQ+ feeding into it.

The decision to use any modern term risks anachronism and mis-labelling people in the past who do not share our cultural frames. Ultimately, the consensus amongst those we consulted was that inaccessibility was a greater evil than anachronism and that researchers' historical judgment could be trusted to place the terms used in their proper context. The terms chosen to identify records are unsurprising: lesbian, gay, bisexual and trans. Furthermore these terms are not seen as the last word on the subject and are subject to regular revision as the political and intellectual landscape changes.

\section{Working Respectfully with Personal Collections}

Set against a background of marginalisation, archives of LGBTQ+ experiences need not only the same level of care and respect afforded to other materials but in some cases more. Many of the collections that will allow us to evidence past LGBTQ+ lives are from individuals and small organisations. These potential or actual depositors often have a personal investment in their collections that may not be the case for professional 
or institutional collections which depositors tend to be more detached from. The way institutions work with personal collections needs to adapt accordingly. As an Engagement and Learning Officer I have an idiosyncratic relationship with the depositing process and am usually involved only at the very beginning and then again at the end. With this perspective in mind I would like to touch on some points of practice that I have found helpful in response to recurring situations.

The parent organisation for LMA is the City of London Corporation (The City). The City is often perceived as being part of the establishment and being small-c conservative. For some people we work with and who may want to deposit with us this reputation is significant and can manifest itself in different ways. I have read volunteer feedback saying that working in a sustained and equal way with a City organisation was a very positive and meaningful experience for them. Conversely, I have talked to people who have said that despite valuing the work that LMA does that they could never deposit their collections in a state archive. Others who are no less wary of state institutions deposit with us so their archives will compliment and challenge existing records and provide LGBTQ+ people with a voice.

As an Engagement and Learning Officer I am one of the public faces of LMA and I often find myself having informal conversations with people who may be interested in depositing records of LGBTQ+ experiences in a formal archive. In light of the discussion in the preceding paragraph even in these informal conversations I now stress that there are different options available to people who are interested in working with an archive to help with the preservation and access to their collections. For those who do not want to deposit with us we can still offer advice on collections care or perhaps alternative repositories. For the wary depositors we can offer arrangements where LMA stores the collection and organises access to it, but the depositor retains ownership of it and can take it back at their discretion.
The bulk of my work with collections occurs once they are in building and are more or less ready for public use in events and community programmes. Again, one needs to be cognisant of the personal investment in these collections when working and the different ways this materialises. LMA has a busy education and community workshop programme and this can be part of the attraction of depositing with us. In these cases, we must make sure we keep our end of the bargain and take the time to immerse ourselves in a new collection and learn how to best interpret and engage people with it. But there is also a need to manage expectations about the scale of engagement in the face of time and financial constraints and the need to balance the competing demands of access and conservation.

A different set of considerations apply when individuals feel that their collections are being used in ways that they didn't expect or feel uncomfortable with. For example, the oral history collection was used as part of an exhibition in the gallery space at LMA. Transcribed sections of interviews were displayed prominently alongside displays of archival material. One of the interviewees invited to the exhibition felt very uncomfortable with her words being used in this way and asked for it to be taken down, which we did. Strictly speaking we did not have to do this as there was implied permission to use the material in this way. In reality though there was a clear obligation to do so despite the cost and inconvenience because of the personal nature of the collection and the distress caused.

\section{Using LGBTQ+ collections in general and dedicated events, education and community programmes}

Our oldest archive of an LGBTQ+ life has become something that I return to again and again when discussing and introducing our collections, the role archives and the puzzle of understanding the past through primary

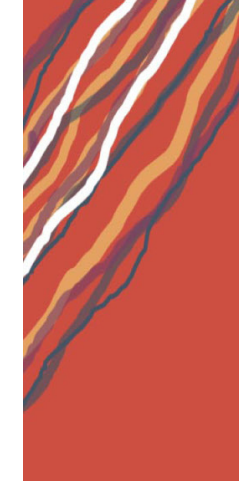


sources. A court document dating from 1395, informally titled The Questioning of Eleanor (John) Rykener, gives us the following account (CLA/024/01/02/035). Eleanor (John) Rykener and John Britby were arrested close to Cheapside in the City of London. Eleanor (John) Rykener was dressed in women's clothes and was working as a prostitute. John Britby had agreed to pay for Eleanor's services. When Eleanor was brought before the Mayor and Aldermen of the City of London, a complex story emerged. Eleanor had slept with many men and women, including members of the church and gentry. Eleanor had also lived and worked as a woman, earning money as an embroideress.

Here we can see evidence of sexual and gender non-conformity that is analogous to modern conceptions of trans and queer. But this instantly raises questions of whether these labels can be properly applied without permission to a person operating in a different milieu on the basis of a single piece of evidence.

Further questions emerge when we add that some scholars argue that rather than being a record of an actual case it is a satire mocking the clergy and gentry that has been inserted into the court roll (Goldberg, 2014). Finally, there is the suggestion that this document had been deliberately hidden from view by omitting it from the authoritative calendar of these records (Boyd and Karras, 1995). A calendar in this case is not something for keeping track of dates, but rather a summary and sometimes translation of a set of records. A reliable calendar is a good enough substitute for the original that there is usually no need to refer to it. Omitting a record from a calendar is thus akin to an act of censorship. This single document therefore begs us to consider the dichotomy between the universal and the particular, authenticity, and the role of the archivist as a gatekeeper of knowledge. The normalisation of once marginal experiences means I can pose these questions to all the groups that I work with be they students or alderman and by doing this it properly locates LGBTQ+ lives as an integral part of London history.

This integration and mainstreaming does raise important questions about how institutions such as LMA work with the histories of marginalised people. A delicate and even contentious aspect of my role is that as a person belonging to many dominant socio-economic and identity groups, I am in a position of validating and interpreting the lives and cultural forms of people who do not belong to these groups. This is an issue I take seriously and it shapes the way I approach both individual events and programming as a whole.

As part of the events programme I lead LGBTQ+ themed walking tour around London. I have led walking tours on various subjects for many years, but I approach these LGBTQ+ ones somewhat differently. The standard format and expectation for most walking tours is pedagogical. The tours guide has knowledge and expertise that the participants do not, and it is the guide job to share this knowledge. At the end of the tours the participants come away better informed on the subject of the walk.

In many contexts this is a valid and useful format and I personally enjoy and benefit from leading and taking part in such walks. But in the context of a LGBTQ+ history walk led by a non-LGBTQ+ person this format would be inadvisable for several reasons.

Firstly, it reinforces the notion that archives, and other institutions are the arbiters of what is included in the historical record. This occurs because it is the employee of the archive who decides what is deemed historical. Secondly, it ignores the importance of lived experience and subjectivity as facets of skilful historical analysis and communication. Thirdly, there is a good chance that at least some of the audience will know more about some of the topics than I do. 
In light of this I have started to think of LGBTQ+ walks as walking discussions in which the guide provides a route, shape and stimulus as well as logistical support, but the content is created in the space between guide and participants. In practical terms what this means is that I will have stops planned ahead of time and am able to provide some background information but when we arrive at each stop, we enjoy a seminar rather than a lecture.

Similar thinking applies to programming decisions more widely and when making decisions about collaboration and content we endeavour to make the process as open, egalitarian and eclectic as possible. To this end I administer several programmes that encourage new and outside perspectives on archives and history from an LGBTQ+ perspective and help LMA to make critical friends along the way. One of these is a monthly workshop programme which is a forum for sharing work and ideas in all stages of development. We think of it as a history laboratory where people are encouraged to experiment and tinker with new ideas as well as a place to demonstrate more finished projects. Topics and forms range broadly from month to month and formal scholarship sits alongside and mixes with more creative approaches. A separate but related programme is a stakeholder's group which provides support and expertise, but also serve as critical friends that can steer us and hold us accountable.

\section{To be continued...}

Documenting LGBTQ+ lives in their plurality and intersectionality has become part of LMA's remit to collect and preserve archives of London and Londoners. This is part of a wider cultural shift in many parts of the world that has seen a change in established attitudes towards gender and sexual minorities as well as new legal rights for LGBTQ+ people. This new cultural context means that archives of LGBTQ+ lives are being treated as less of a unique and hermetic subset of records and more as entry points into broader discussions around historical inquiry and topics including identity, diversity and conformity.

There is much to be welcomed in the current situation. It is a timely corrective to persecution, and speaking selfishly, it makes the work of an Engagement and Learning Officer more stimulating. But some caution against complacency and haste is necessary too. Its very easy for people such as myself to think that the worst is behind us, read an introductory text on queer studies, and pat ourselves on the back for being critical and open minded and then carry on with something like business as usual. To guard against this we also need to welcome guidance and reality checks from critical friends and stakeholders. Ideally, an archive is a forum for enquiry and conversation rather than conclusions. This piece and especially my personal reflections contained in it are offered in the same spirit.

\section{References}

Boyd, David Lorenzo, and Ruth Mazo Karras. 1995. "The Interrogation of a Male Transvestite Prostitute in Fourteenth-Century London.” GLQ 459-465.

Corporation of London Records Office, Plea and Memoranda Roll A34, m.2 (1395) CLA/024/01/02/035

Goldberg, Jeremy. 2014. "John Rykener, Richard II and the Governance of London." Leeds Studies in English.

Marwick, Arthur. 2001. "The Fundamentals of History.” History in Focus .
SQS

$1-2 / 2020$

Queer

ViewMirror

Opinion

Pieces

Pieces

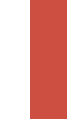

